\title{
5 Securing Understanding in a Second Language
}

\section{Communication of Rights in Investigative Interviews in the US and Norway}

\author{
Pawet Urbanik and Aneta Pavlenko
}

\section{Introduction}

In 1966, the General Assembly of the United Nations (UN) adopted the International Covenant on Civil and Political Rights (ICCPR), subsequently signed and ratified by 168 states. Article 14 of the ICCPR declares that suspects have a fundamental right to be presumed innocent and outlines several concomitant rights, including the right to be informed about the charges in "a language which [the suspect] understands" and the right "not to be compelled to testify against himself or to confess guilt" (United Nations 1966). To ensure a common standard across member states in safeguarding these rights, in 2012 the European Parliament and the Council of the European Union (EU) issued a Directive on the right to information in criminal proceedings. Article 3 of the EU Directive requires member states to provide suspects under arrest with a letter outlining the following procedural rights, as they apply under national law: (a) the right of access to a lawyer; (b) any entitlement to free legal advice and the conditions for obtaining such advice; (c) the right to be informed of the accusation; (d) the right to interpretation and translation; and (e) the right to remain silent (European Union 2012).

Many non-EU states have similar provisions, but there is also great jurisdictional variation, within and outside of the EU, involving: (a) mandatory rights; (b) the mode of communication (in the US the rights are scripted, while in Norway investigators articulate them in their own words); (c) negative provisions (England and Wales require a provision that outlines the negative consequences of remaining silent, while in Denmark and the US the right to silence is unconditional); and (d) rules that govern invocation of the rights (in the US police are required to stop the interrogation when suspects invoke their right to silence, while in Canada and the Netherlands investigators are allowed to continue questioning).

The variation across jurisdictions makes it unreasonable to expect all individuals to be familiar with their rights. Instead, article 14 of the ICCPR declares that suspects should be informed of their rights in a language they understand. The 2012 EU Directive restates this requirement and adds further provisions: suspects should be given the Letter of Rights, written in 
simple and accessible language. Unfortunately, the EU Directive offers no definition of simple and accessible language. In fact, the very sentence on language rights in its model letter violates plain language precepts: "If you do not speak or understand the language spoken by the police or other competent authorities, you have the right to be assisted by an interpreter, free of charge" (European Union 2012, 8).

Similar sentences, articulated with lawyers in mind, appear in scripted rights used in Australia, England and Wales, and the US. Not surprisingly, research conducted in these settings shows that even native speakers of English do not always fully understand their rights and the consequences of waiving them (Rock 2007; Rogers et al. 2013). When it comes to second language (L2) speakers, the prevailing assumption is that they are wellserved by existing procedures: those who do not understand the language in question get an interpreter, and those who do comprehend the warnings. Recent studies contradict these assumptions and show that many L2 users fall into a grey area: able to communicate on a variety of everyday subjects, they lack the background knowledge and language skills to understand their rights and the consequences of waiving them (Bowen 2019; Eades 2018; Innes and Erlam 2018; Pavlenko, Hepford and Jarvis 2019). This research, however, has been limited to English-speaking countries that rely on scripted rights. The present study takes a further step: we compare communication of scripted (US) and unscripted (Norway) rights. First, however, we need to tackle a tricky question: what does it mean to understand one's rights?

\section{Psycholinguistic and Sociolinguistic Approaches to the Study of Understanding in an L2}

The legal standard for informed consent is satisfied when suspects are formally advised of their rights. An affirmative answer to the yes-or-no question "Do you understand?" and a signature on the waiver of rights count as evidence of understanding (Ehrlich, Eades and Ainsworth 2016). Psychologists who evaluate understanding of rights have more exacting standards: their conclusions are based on the adequacy of paraphrases, recall, inferences, and answers to comprehension questions (Rogers and Drogin 2019).

In the field of Second Language Acquisition (SLA), L2 listening comprehension is defined as an ability to process spoken L2 automatically and in real time and to understand the information relayed by the interlocutor (Bloomfield et al. 2010; Ellis 2008; Vandergrift and Baker 2018). Factors that affect L2 comprehension are divided in this research into three categories. Individual factors include working memory capacity, vocabulary size, strategic competence, extent of previous L2 exposure, background knowledge, and listener anxiety, shown to negatively affect the ability to understand what is being said. Text characteristics encompass passage length, morphosyntactic complexity, information density (i.e., the number of ideas per passage), redundancy, concreteness, directness, idiomaticity, and word 


\section{Pawet Urbanik and Aneta Pavlenko}

frequency. Context-wise, L2 comprehension is negatively affected by time limits, background noise, unfamiliar accents, and fast speech rates. SLA studies also show that listening comprehension can be facilitated by repetition and presentation in two modes, oral and written.

The factors particularly pertinent to communication of rights include anxiety (extremely high in the context of police interrogation) and the wording of rights. Research shows that scripted rights are distinguished by (a) information density; (b) reliance on legal jargon and low-frequency terms; and (c) syntactic complexity (Berk-Seligson 2009, 2016; Eades 2010, 2018; Eggington and Cox 2013; Pavlenko 2008; Shuy 1997). This is not to say that L2 speakers draw a blank, when faced with complex stretches of talk. Listening comprehension, as Ellis (2008) reminds us, is not just a bottom-up process of matching sound to meaning - it is also a top-down process, in which L2 learners make inferences, using their background knowledge.

To see how the two processes interact, Pavlenko, Hepford and Jarvis (2019) compared understanding of the US rights, commonly known as the Miranda warnings, among first language (L1) $(\mathrm{n}=41)$ and L2 speakers of English $(n=59)$. Most of the L2 speakers were deemed advanced, i.e., level B2 or higher, according to the Common European Framework (CEFR), and were enrolled in upper-level English as a Second Language (ESL) courses. The warnings, recorded by a state trooper, were played one sentence at a time, and students had to write each sentence down in their own words. The analysis revealed that only two L2 speakers $(3.4 \%)$ reached the minimum comprehension threshold on the task.

To tease out the factors that affect the understanding of rights, Pavlenko and associates (2019) administered a word definition task and a listening comprehension task with sentences involving legal and non-legal content to L1 $(\mathrm{n}=82)$ and L2 $(\mathrm{n}=183)$ speakers. The analysis confirmed the negative effects of sentence complexity and low-frequency words on L2 comprehension, but three findings were utterly unexpected. First, the researchers found a difference between L1 and L2 speakers in comprehension of high-frequency polysemic words, such as "right" and "exercise." Both groups were familiar with their concrete meanings (right/left, right/ wrong; physical exercise, academic exercise), but only a few L2 speakers were aware of their abstract and collocational meanings (human rights, exercise one's rights). Second, to fill gaps in understanding, L2 speakers inferred meanings from context based on phonological similarity and approximate semantic fit. Unfortunately, in the context of legal warnings, these compensatory strategies led them astray: the phrase "You have the right to have a lawyer present" was paraphrased by some as "You have the right to have a lawyer in prison"; the term "waiver" was interpreted as "a document that safeguards your rights" and the collocation "exercise rights" as "workout rights" or "rights to physical exercise." The third and the most disconcerting finding was that these paraphrases made perfect 
sense to the participants - when a subgroup of L2 speakers was asked to rate their confidence in their own comprehension, they gave themselves consistently high ratings.

These findings raise great concerns regarding understanding of scripted rights by L2 speakers, but they are limited in two ways. Firstly, they do not tell us anything about understanding of unscripted rights; and, secondly, they treat comprehension as a solitary pursuit. Studies of communication of rights in police interviews remind us that understanding is a joint discursive accomplishment that relies on verbal and non-verbal strategies and cues (Berk-Seligson 2002, 2009; Bowen 2019; Eades 2018; Ehrlich, Eades and Ainsworth 2016; Heydon 2005; Pavlenko 2008; Rock 2007, 2016). What makes this accomplishment challenging is the power asymmetry: investigators control the timing and the mode of the delivery of the rights, while suspects follow - or, for that matter, fail to follow - suit. Researchers have not yet examined conversational strategies that could potentially facilitate understanding of rights, such as repetition, reformulation, elaboration, comprehension checks, and clarification requests (cf. Svennevig et al. 2019, on reformulation and simplification in L2 interaction). The present study, therefore, has a dual aim: (a) to compare communication of scripted (US) and unscripted (Norway) rights in police interviews; and (b) to examine the use of conversational strategies that shape the understanding of rights.

\section{Communication of Rights in Investigative Interviews}

\section{Communication of Rights in the US}

\section{Legal and Procedural Foundations}

The main purpose of investigative interviews in the US is to obtain the suspect's confession (Inbau et al. 2013). The perilous side effect of such orientation are false and coerced confessions, obtained through physical abuse, intimidation, threats of harm or punishment, deception, deprivation of basic needs, prolonged and exhausting interrogations, and manipulation of suggestible suspects (Gudjonsson 2018; Leo 2008). To ensure due process and to safeguard suspects and the court against false and coerced confessions, in 1966 the US Supreme Court made the following decision in the case of Miranda v. Arizona:

The person in custody must, prior to interrogation, be clearly informed that he has the right to remain silent, and that anything he says will be used against him in court; he must be clearly informed that he has the right to consult with a lawyer and to have a lawyer with him during interrogation, and that, if he is indigent, a lawyer will be appointed to represent him. 


\section{Pawet Urbanik and Aneta Pavlenko}

Once informed of their Miranda rights, suspects may invoke them, in which case the investigator must stop the interview, at least until the lawyer's arrival. Alternatively, suspects may choose to waive their rights, "provided the waiver is made voluntarily, knowingly, and intelligently" (Miranda $v$. Arizona 1966, 444), i.e., "with a full awareness of both the nature of the right being abandoned and the consequences of the decision to abandon it" (Moran v. Burbine 1986, 421). If the defense can prove later that the defendant waived their rights unknowingly, unintelligently, or involuntarily, inculpatory statements may be deemed inadmissible by the judge, thus weakening the basis for a conviction. Nevertheless, overviews of cases involving L2 speakers show that judges tend to find waivers valid, even if an individual later required an interpreter (Berk-Seligson 2009; Einesman 2010; Pavlenko 2008; Villalobos and Davis 2016).

The warnings, however, aren't as simple as they are purported to be. For starters, the Miranda warnings are scripted but not standardized - each jurisdiction has its own version, which means that at any given time there are more than a thousand texts in circulation. Analyses of 945 Miranda texts revealed substantive variation in (a) length (between 49 and 547 words); (b) content; (c) vocabulary; (d) sentence complexity; and (e) comprehensibility (grade 2.8 to post-graduate) (Rogers et al. 2007, 2008). Furthermore, investigators are allowed to use manipulation, deception, and trivialization strategies that frame the waiver as a routine bureaucratic procedure and steer the suspect towards consent (Leo 2008; Scherr and Madon 2013). In the view of the leading legal expert, Richard Leo (2008), misrepresentation of the nature and purpose of questioning is one of the most fundamental and overlooked deceptive strategies in US police interviews. To compare different approaches to communication of rights in the US, we will analyze excerpts from two video-recorded police interviews.

\section{Data Analysis ${ }^{1}$}

The first extract comes from a police interview of a Russian national, which was retranscribed and reanalyzed for the purposes of the present study by the second author, who appeared as a forensic expert in the case (Pavlenko, 2008). Analysis that triangulated the suspect's (S) linguistic performance with her test scores and grades placed her English proficiency at the highintermediate level. To conceal gaps in understanding, she relied on her interactional competence, i.e., the ability to derive meaning from verbal and non-verbal cues. The investigator, however, was adept at manipulating such cues. The suspect was invited to the police headquarters as a witness in an ongoing investigation. Following an informal exchange, the investigator (I) shifted into the formal mode to introduce the Consular notification, obligatory in cases of the arrest or detention of foreign nationals, and managed to present it without alerting the interlocutor to the fact that she was in custody. To keep her talking before she was formally charged, he followed the same tack in delivering her rights. 


\section{Extract 1}

01 I there's another one I have to do =

$02 \mathrm{~S}=\mathrm{OK}(($ smiles and nods $))=$

$03 \mathrm{I}=\mathrm{I}$ want to read you that one (.) OK? (.)

$04 \mathrm{~S} \quad($ nods silently))

05 I then we'll we'll get by all of that (.)

06 and then you will sit (.)

07 and I'll have my coffee (.)

08 and you can have some more water (.)

$09 \quad$ what do you think?

$10 \mathrm{~S}$ all right=

$11 \mathrm{I}=\mathrm{OK}(($ laughs $))($.$) here let me read this one to you (.)$

$12 \mathrm{uhm}($.$) if there's any part of this that you don't understand let me$

13 know=

$14 \mathrm{~S}=\mathrm{OK}=$

$15 \mathrm{I}=\mathrm{OK}($.$) this is who I work for (.) ((name of police department$

16 omitted)) and this says Miranda Warning Form (.)

17 and this is just your name (.)

18 and then there are some numbers I'll fill in ((waves his left hand in a

19 dismissive manner)) [there [you like read this for everybody $\uparrow$ (.)

22 I this is when we're sitting and talking (.) anybody (.)

23 whether [it's

$24 \mathrm{~S} \quad$ [like Michael signed this? = ((here a short segment is omitted to prevent identification))

27 United States too $=$

$28 \mathrm{~S}=$ OK so they do the same thing?

29 I yeah ((nods several times))

30 I you have the right to remain silent (.)

31 anything you say can and will be used against you in a court of law (.)

32 you have the right to talk to a lawyer and to have him present with you

33 while you are being questioned (.)

34 if you cannot afford to hire a lawyer (.)

35 one will be appointed to represent you before any questioning

36 if you wish one (.)

37 if at any time during this interview

38 you wish to discontinue your statement

39 you have the right to do so (.)

40 do you understand each of these rights I have explained to you?

$41 \mathrm{~S} \quad(($ suspect nods silently))

42 I (.) OK good $\downarrow$ (.)

43 having these rights in mind do you wish to talk to us now? =

$44 \mathrm{~S}=$ right $($.$) of course =$

$45 \mathrm{I}=\mathrm{OK}($.$) let me give you [that$

$48 \mathrm{I}=$ let me get you to sign right there on the top line (.) thank you 


\section{Pawet Urbanik and Aneta Pavlenko}

In the view adopted here, this interview is an example of what Rock (2016) terms "tick-box consent." Aware that he is being video-recorded, the detective is delivering the rights "by the book" - slowly and with the written text visible to the suspect. At the same time, he frames the waiver as a formality that applies to all interviews (line 22). When the suspect, unfamiliar with the Miranda warning, checked to see whether this form was also for foreigners (line 21), the investigator replied that they do it for people in the US too (lines 26-27), without specifying that it is only used with suspects in custody. To reinforce the misunderstanding, he told the suspect that her friends, interviewed as witnesses, also signed the form (in court, he was forced to admit it was a lie). When she signaled her lack of understanding of the right to silence (lines 46-47), the detective ignored her question and asked her to sign the document. Unfamiliar with US law, the suspect signed the waiver under the false impression that witnesses are required to do that. When the suspect's attorney filed a motion to suppress her statements based on the second author's testimony that she did not have sufficient proficiency to understand her rights, the Superior Court of Delaware denied the first part of the motion. "I find that her comment '[h]ow can you be silent if you brought me in to talk," wrote Judge Vaughn in his opinion, "was simply a choice of words on her part indicating that she wished to answer questions" (State $v$. Malinovskaya 2006).

The second interview exemplifies a dialogic approach to communication of constitutional rights. The excerpt comes from a repeat encounter between an investigator and a suspect awaiting a trial in jail. Given the fact that the defendant had already been advised of her rights during preceding interviews and had retained an attorney, it would have been tempting to treat the delivery of the Miranda rights as a formality. Instead, the investigator re-delivered the rights according to his own "playbook."

\section{Extract 2}

01 I I gotta go through a couple more things here: $\uparrow$

02 that I have to get out of the way $\uparrow$

03 and we can talk freely OK? ((open gesture with both hands)) so (.)

$04 \mathrm{~S} \quad(($ nods $))$

05 I ((starts filling out the paperwork))

06 this is the Miranda Warnings again

07 but I do it a little different when we are in this type of setting (.) OK?

08 I'm ask you/I'm gonna ask you some questions ((enunciates very precisely))

09 whatever you tell me I'm gonna write it down (.) OK?

10 so the time now is gonna be: (.) twelve oh one pm ((writes down))

11 ((stops writing, turns to $\mathrm{S})$ )

12 when can you have an attorney?

$13 \mathrm{~S}$ when?

$14 \mathrm{I}$ when can you have an attorney?

$15 \mathrm{~S}$ when I needed it $\downarrow$

16 I when you need it? 
$17 \mathrm{~S}$ yeah::

18 I when I needed it?

19 so basically you can have an attorney any time that you want one

20 any time you want an attorney ((open gesture with both hands $))=$

$21 \mathrm{~S}=$ oh no when I get in trouble $\uparrow$

22 I so when can you have an attorney?

23 what would be your answer to that question?

$24 \mathrm{~S}$ when you get in trouble?

25 I well (.) I would say (.) I'd say any time you want one

$26 \mathrm{~S}$ oh ((laughs)) any time if you want one $\uparrow$

27 I so: when can you have an attorney?

$28 \mathrm{~S}$ any time if you want one! ((laughs))

29 thank you for helping me! ((giggles))

30 see: I am not that good $\uparrow$

31 I'm not a good liar either $\uparrow$

32 I can you have an attorney any time that you want one including right now?

$33 \mathrm{~S}$ right now? yes $\downarrow$

34 I can you use my telephone (.) free of charge (.) to call an attorney?

$35 \mathrm{~S}$ yes $\downarrow$ ((nods))

36 I what will happen if you want an attorney but you can't afford one?

$37 \mathrm{~S}$ the state will offer it to you $\downarrow$

38 I the state will appoint one?

$39 \mathrm{~S}$ aw: yes $\uparrow(($ nods enthusiastically $))$

40 I I'll put "the state will offer it to you" $\downarrow$ ((writes down))

41 do you have to answer even one of my questions or say anything to me at all?

$42 \mathrm{~S}$ no $\downarrow$

43 I if you start to answer my questions and then decide that you wanna stop

44 can you stop any time that you want?

$45 \mathrm{~S}$ I don't know? ((looks at the investigator)) yes ((giggles))

46 are you OK?

47 I yeah: you don't ... you don't have to talk to me if you don't

48 you do not have to talk to me at all OK?

49 this is completely voluntary

50 do you understand that if I am called into court

51 to testify about what both you and I say

52 that I will be placed under oath and I will tell the truth?

$53 \mathrm{~S}$ yes $\downarrow$

54 I would you want me to tell the truth or would you want me to lie?

$55 \mathrm{~S}$ I want you to tell the truth $\downarrow$

56 lying does not help you $\downarrow$

57 I do you understand that I will tell the complete truth

58 regardless of whether it helps/helps or hurts the police or helps or hurts you?

59 ((points to her)) yes?

$60 \mathrm{~S}$ yes $\downarrow$

$61 \mathrm{I}$ now that you know all of your rights do you wish to continue with this polygraph?

$62 \mathrm{~S}$ yes ((nods))

63 I what I need you to do is to look down through that

64 make sure that's what we talked about

65 what I wrote down is what you told me

66 put your initials at the bottom if you agree with the front page 


\section{Pawet Urbanik and Aneta Pavlenko}

67 and then read the back of it ((gives her the pad with the document and a pen))

$68 \mathrm{~S}$ ((takes the pad, looks at it)) so: how long you are doing this one?

69 I what's that?

$70 \mathrm{~S}$ how long you've been doing this one?

$71 \mathrm{I}$ this? some many years $\downarrow$

$72 \mathrm{~S}$ so, if I have a felony charge $\uparrow=$

$73 \mathrm{I}=$ hold on (.) hold on (.) let's get this out of the way first ((both laugh)),

74 I know you are excited to talk but I gotta get this done first

75 go through this (.) make sure that's all what we talked about

76 I need you to read through that and I need you to put my name down right here

This segment shares several similarities with the previous interview: both investigators speak in a brisk professional manner, frame the documents as something they have to complete (Extract 2, lines 1-2, 7, 73-74), and refer to them in a casual manner as things to get out of the way (Extract 2, lines $1-2,73)$. The difference lies in securing understanding: the first investigator satisfied the Miranda requirement with formal delivery of the rights, while the second one adopted an active dialogic approach. To ensure that the suspect understood her rights, he asked numerous comprehension questions (lines 12, 14, 22, 27, 32, 34, 36, 41, 43-44, 50-52, 54, 57-58, 61), and when she displayed hesitation or a lack of understanding of a particular right, he offered further explanations, repeating and/or rephrasing the same information (lines 19-20, 25, 47-49) and adding additional vocabulary (line 38).

Together, the extracts show that US investigators have a variety of strategies at their disposal: some may trivialize the Miranda waiver as a routine procedure, and others scaffold understanding through explanation, elaboration, and repetition and evaluate it with the help of paraphrasing, comprehension checks, and clarification requests. In the cases above, the two distinct approaches led to the same outcome: both suspects signed the waiver, with the difference that the second suspect actually displayed understanding of her rights.

\section{Communication of Rights in Norway}

\section{Legal and Procedural Foundations}

In Norway police investigators are expected to follow an investigative method known as KREATIV (Fahsing and Rachlew 2009). ${ }^{2}$ Based on the PEACE framework developed in England and Wales in the 1980s and 1990s, this approach aims to move away from the confession-oriented, confrontational, and coercive interrogation style favoured in the US and towards research-based and information-oriented interviewing (Fahsing and Kepinska Jakobsen 2016; Fahsing and Rachlew 2009; Gudjonsson 2018, 45-48; Shawyer, Milne and Bull 2009). According to the KREATIV model, the purpose of the interviews with suspects is to gather information 
by giving the suspects an opportunity to tell their own version of events, listening actively, and building trust and rapport through interaction (Fahsing and Rachlew 2009).

The acknowledgment of the suspect's rights is one of the key elements of rapport building and respectful communication, and it is explicitly manifested early on during the interview, namely when the suspect is being formally familiarized with his/her legal rights. The recommended way of securing their understanding is to (1) present the rights in a way that is understandable for a given suspect, and (2) ascertain that the rights have been understood correctly (cf. Bjerknes and Fahsing 2018, 219-220). This becomes even more important when suspects belong to one of the vulnerable populations (juveniles, individuals with physical or intellectual disabilities, L2 speakers, etc.) for whom the KREATIV model is meant to show special concern (Bjerknes and Fahsing 2018; Fahsing and Rachlew 2009).

In the information phase of Norwegian investigative interviews, suspects receive a package of rights, obligations, and other cautions. In the KREATIV model this phase is called "Kontaktetablering og introduksjon" (Contact Establishing and Introduction), which corresponds to the "Engage and Explain" stage in the PEACE framework. The main purpose of this phase is to familiarize suspects with formal requirements and procedural steps, but also to build trust and create good atmosphere (Bjerknes and Fahsing 2018, 216).

The procedure in this phase basically follows the regulations of the Straffeprosessloven (Criminal Procedure Act [CPA]), the Pataleinstruksen (Prosecution Instructions [PI]), the Rundskriv fra Riksadvokaten (General Prosecutor Directive on Police Interview [Directive]) of 2016, and the Straffeloven (Penal Code). According to the CPA, PI, and Directive, the interviewee should be informed about several issues. First, s/he should know that the interview is being recorded. Next, s/he should be given the reason why s/he is being interviewed and what his/her legal status is (i.e., victim, witness, expert, suspect, or charged). Third, the suspect or charged party should be informed about his/her right to silence and a defense counsel. Fourth, s/he should be made aware of the possibility of a reduced sentence (typically called a "sentence discount") for cooperation. Fifth, if s/he is willing to testify, s/he should be encouraged to give truthful statements. In addition, the suspect can be discouraged from giving false statements, if this is relevant to the case. Table 5.1 presents the components of the information phase with their legal bases in the order they usually appear.

In Norway the right to silence is formulated as a lack of obligation to give a statement. This right, together with the first two components of the information phase, is worded in the PI as follows:

Før det foretas avhør med mistenkte, skal han gjøres kjent med hva saken gielder og med eventuell siktelse. Han skal giøres kjent med at han ikke har plikt til å forklare seg. 
Before an investigative interview with a suspect is carried out, he shall be informed about the case and a possible charge. He shall be informed that he has no obligation to give a statement.

(Prosecution Instructions $\mathbb{8} 8-1$, first paragraph, translated by PU)

The right to counsel is formulated as the possibility of engaging the assistance of a defence attorney, chosen by the suspect, at each stage of the investigation:

Mistenkte skal dessuten gjøres kjent med at han har rett til å la seg bistå av en forsvarer etter eget valg på ethvert trinn av saken, herunder ved politiets avhør av ham. Siktede bør spørres om hvem han ønsker oppneunt som sin offentlige forsvarer når han har krav på slik forsvarer. The suspect shall in addition be informed that he has the right to be assisted by a defence counsel of his choice at each stage of the investigation, including the police investigative interview with him. The charged should be asked whom he wishes to be appointed as his public defender when he is entitled to such a defender.

(Prosecution Instructions $\mathbb{S} 8-1$, second paragraph, translated by PU)

Unlike in the US, legal rights in Norway are not scripted, which means that police officers can articulate them in their own words. As a result, one might expect lexico-grammatical variation. Furthermore, although the interviewer is required to deliver the information package in an understandable way

Table 5.1: Legal bases for the components of the information phase in police interviews in Norway

\begin{tabular}{lllll}
\hline & $\begin{array}{l}\text { Criminal } \\
\text { Procedure } \\
\text { Act }\end{array}$ & $\begin{array}{l}\text { Prosecution } \\
\text { Instructions }\end{array}$ & $\begin{array}{l}\text { The General } \\
\text { Prosecutor } \\
\text { Directive }\end{array}$ & $\begin{array}{l}\text { Norwegian } \\
\text { Penal Code }\end{array}$ \\
\hline $\begin{array}{l}\text { 1. Recording (audio/video) } \\
\begin{array}{l}\text { 2. Status } \\
\text { (suspect or charged) }\end{array}\end{array}$ & $\mathrm{X}$ & $\mathrm{X}$ & $\mathrm{X}$ & \\
$\begin{array}{l}\text { 3. Case } \\
\text { (reason for interviewing) }\end{array}$ & $\mathrm{X}$ & $\mathrm{X}$ & $\mathrm{X}$ & \\
$\begin{array}{l}\text { 4. Right to silence } \\
\text { 5. Right to counsel }\end{array}$ & $\mathrm{X}$ & $\mathrm{X}$ & $\mathrm{X}$ & \\
$\begin{array}{l}\text { 6. Possibility of sentence } \\
\text { reduction }\end{array}$ & $\mathrm{X}$ & $\mathrm{X}$ & $\mathrm{X}$ \\
$\begin{array}{l}\text { 7. Warning against false } \\
\text { statement }\end{array}$ & & $\mathrm{X}$ & $\mathrm{X}$ \\
$\begin{array}{l}\text { 8. Encouragement to give a } \\
\text { truthful statement }\end{array}$ & $\mathrm{X}$ & $\mathrm{X}$ & $\mathrm{X}$ & \\
\hline
\end{tabular}


and secure the comprehension of its components (Bjerknes and Williksen 2015; Riksadvokaten 2016; Bjerknes and Fahsing 2018, 216), there is no guidance on how to determine the need for an interpreter or how to adapt the wording of the rights to the perceived language proficiency of a suspect.

\section{Data Analysis ${ }^{3}$}

Norwegian investigators informing suspects about their rights and obligations tend to stick to the wording of the PI. This shows that, despite the absence of a scripted formula, the delivery of the rights to silence and to an attorney is not "unscripted" - to fulfil their obligations, investigators rely on the language of the law (cf. Bowen 2019). The analysis examines two different approaches adopted by Norwegian investigators.

In the first approach, exemplified in Extract 3, the information phase is treated as a formality that needs to be checked off, what Rock (2016) terms "tick-box consent." The interview is conducted with an L2 speaker of Norwegian. In the sequence below, the investigator (I) informs the suspect (S) about his rights after having notified him of recording and having collected his personal details.

\section{Extract 3}

01 I klokka e:r, (0.5) null tre femten The time is zero three fifteen $\dot{c}$

$02 \quad(1.8)$

03 I å så: ønsker je::g e: først å gjøre deg oppmerksom And I want to first inform you

04 på dine rettigheteri about your rights $\check{c}$

$05 \quad(0.4)$

06 I du har ingen plikt til å forklare deg for politietc You have no obligation to give a statement to the police:

$07 \quad$ (.)

$08 \mathrm{~S} \mathrm{mhm}$,

$09 \quad(0.5)$

10 I du har rett $>$ til å la dæe bistå av en forsvarer You have the right to be assisted by a defence counsele

11 (.)

$12 \mathrm{~S} \quad \mathrm{~m}\left[::_{-}\right]$

13 I [på ethve]rt trinn av sakenc

At each stage of the investigation $\dot{c}$

$14 \quad$ (.)

$15 \mathrm{~S} \downarrow \downarrow \mathrm{m}::$,

$16 \quad(0.6)$

17 I å så vil jeg fortelle dæ at (0.9) nå:ㅁ man

And I want to tell you that when one

18 forklarer seg for politiet om e noe man e::

gives a statement to the police about something one 
(0.8) blir mistenkt for $\dot{c}$ is suspected of $\dot{c}$

20

$21 \mathrm{~S}$

(.)

$\uparrow \mathrm{m}::$.

så kan man få en (0.8) strafferabatt’ (0.6) en then one can get a sentence discount a

3 mildere straff $_{i}(0.8)$ dersom man: innrømmer, lighter sentence if one admits,

4 (0.7) det man har [gjort_] the thing one has done

\section{6 noen feil. \\ anything wrong.}

$27 \quad(0.5)$

28 I $\downarrow$ nei.

$$
\text { No. }
$$

$29 \quad(1.0)$

30 I jeg skal forklare deg hva jeg ønsker at du skal I will explain to you want I want you to

31 forklare $\uparrow$ deg om $\dot{c}$ give a statement about $\dot{c}$

In lines 03-04, the investigator marks a new phase of the interview by announcing what he is going to do next. Right after that, he starts listing the suspect's rights. He does that incrementally, marking prosodically each unit as an incomplete part of a larger structure and separating it from the other ones with longer pauses. This way of presenting information (in instalments) has been described as a pre-emptive comprehension strategy, often used by L1 speakers in interaction with L2 speakers (Svennevig 2018). The purpose of the chunking is to give the recipient an opportunity to signal understanding problems after each separate unit. Thus, the formulations of the legal rights in our example are identical to those found in the PI (see above), but they are delivered in a way that opens a slot for the suspect to react. Having received a back-channelling signal (a continuer) from the suspect ("mhm" or "m::"), which normally encourages the continuation of the turn, the investigator simply goes to another component of the information phase without checking the understanding of the right that has been presented or even asking whether the suspect is willing to exercise it. This may be the result of a stronger sequential interdependence between the conversational turns, whereby the design of instalments may prompt continuers as cooperation markers that indicate absence of understanding problems (Schegloff 1982). Thus, since the suspect does not display any comprehension difficulties or exercise his rights at this point, the investigator continues, 
revealing his assumption that the suspect is willing to give a statement (line 30). This leads to questions (not quoted here) to which the suspect does not give clear answers, claiming he did not do anything wrong by having an imitation firearm in his car. The investigator eventually interprets the suspect's responses as refusal to give a statement, although the latter had not been asked whether he wanted to give it at all.

The information phase also displays several procedural shortcomings. First, it lacks other components, i.e., information about the possibility of a reduction in sentence length and encouragement to give a truthful statement. Furthermore, the order of the components deviates from the policies and the usual practice (cf. Bjerknes and Williksen 2015). The suspect is informed of the reason for being interviewed not at the beginning but at the end of the information phase, after which the investigator starts asking questions. Consequently, what becomes locally relevant for the suspect is to answer to the accusation rather than relate to the rights since these are already relegated sequentially to less significant information.

The second way of informing suspects about their rights and obligations is characterized by contextual adjustment of the wording. Investigators still formulate the components in legalese, but they reformulate and simplify them attempting to secure comprehension by engaging the suspect in the clarification process. This is exemplified in Extract 4 where the investigator interviews a juvenile L2-speaking suspect.

\section{Extract 4}

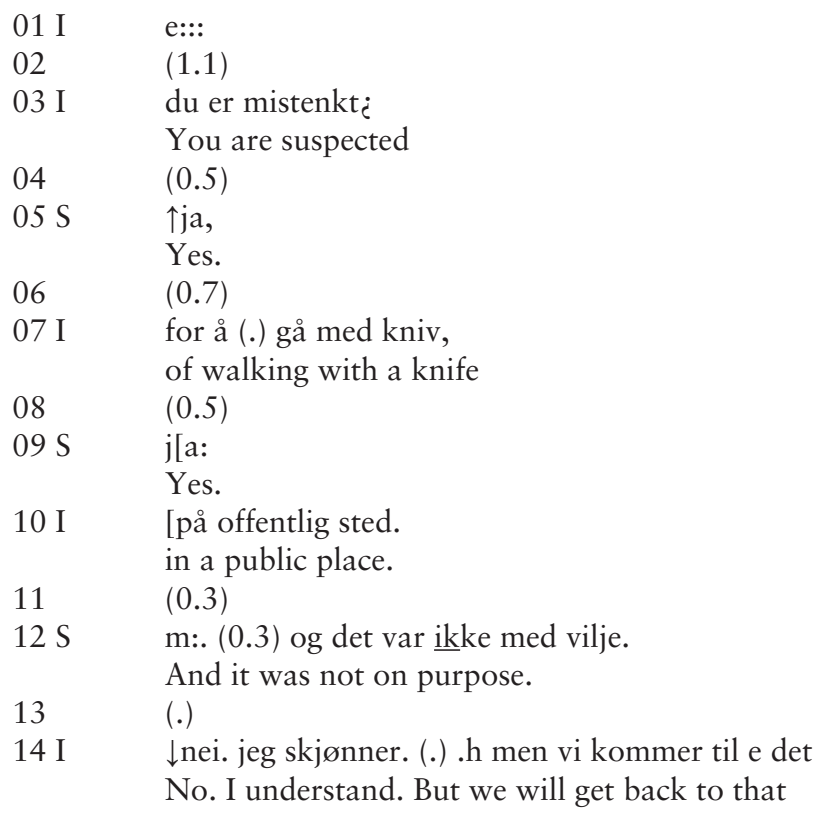

13 (.)

14 I \nei. jeg skjønner. (.) .h men vi kommer til e det No. I understand. But we will get back to that 
15 etter hvert, (0.5) .h e::: (.) du har ikke plikt later. You do not have obligation

16 til å forklare deg for politiet ¿ to give a statement to the police.

$17 \quad(0.5)$

$18 \mathrm{~S} \quad \uparrow \mathrm{mh}$

Mhm.

$19 \quad(0.9)$

20 I skjønner du hva det betyr $\dot{c}$

Do you understand what it means?

$21 \quad$ (.)

$22 \mathrm{~S} \quad(\downarrow$ nei) jeg tror det. (No), I think so.

23 (.)

$24 \mathrm{I}$ ja. (.) du må ikke forklare $\uparrow$ deg, (0.7) du må ikke Yes. You do not have to give a statement. You do not have to 25 svare på mine spørsmål. answer my questions.

$26 \quad$ (.)

$27 \mathrm{~S} \quad \uparrow$ jo jeg kan (det).= Yes, I can (do this).

28 I =åkej. (.) .hh e::: (0.8) og du har rett til å ha Okay. And you have the right to have

29 en advo $\uparrow$ kat, a lawyer.

$30 \quad(0.6)$

$31 \mathrm{~S} \quad \uparrow \mathrm{m}:$

Mhm.

$32 \quad(1.0)$

33 I og du har også rett til å ha en advokat til stede And you also have the right to have a lawyer present

34 når du snakker med politiet‘ when you are talking to the police.

$35 \quad$ (.)

$36 \mathrm{~S} \quad \uparrow j a$ det vet jæ.

Yes, I know that.

$37 \quad$ (.)

38 I ja. (.) .hh e::: (0.4) men du har ikke noe advokat Yes. But you do not have any lawyer

39 her (0.3) nåc (0.6) e: så da er spørsmål om du er here now, so the question is if you are

40 villig til å forklare deg (0.9) $\underline{\uparrow n a ̊ ~ u t e n ~ a d v o k a t ~}$ willing to give a statement now without a lawyer

41 til stede. present.

$42 \quad$ (.)

$43 \mathrm{~S} \quad \uparrow n e i \uparrow j e g$ kan: si:: det som jeg tenker.

No, I can say what I think. 
After notifying the suspect that he will record and collect his personal details, the investigator first informs him about his status and the reason for why he is being interviewed. Then, the suspect receives information about his rights. In contrast to the previous extract, the investigator explicitly asks him whether he understands the right to silence and having received a positive but epistemically downgraded response that reveals uncertainty (jeg tror det [I think so]), he reformulates the right (lines 24-25). A simplified wording leads to a resolute response in which the suspect waives his right (line 27). Then, the right to counsel is presented in three parts. The first part is a simplified version of the official wording (lines 28-29). Here the investigator does not directly employ the formulation from the PI but makes use of simpler expressions and terms, such as an internationally recognizable term "advokat" ("lawyer") instead of "forsvarer" ("counsel"). The second part is a simplified specification that explains the applicability of the right during investigative interviews (lines 33-34). The third part narrows down the right to the local situation (lines 38-41). This contextualization serves as a point of departure for a direct question about whether the suspect indeed wants to wave this particular right together with the right to remain silent. Consequently, the investigator creates yet another opportunity to ascertain that the suspect has understood his rights and that his responses are consistent in this matter. Only after this part is finished does the interviewer provide simplified information about sentence discount, which is followed by additional questions from the suspect.

The comparison of the two approaches leads us to several observations concerning the Norwegian investigative system. First, although this system does not offer scripted cautions, the investigators tend to rely on the official formulations in the law (the PI). Second, variation in the wording depends on the extent to which the investigator engages himself and the suspect in the information phase by adjusting the formulations to the local context. Yet, any conflict between procedural and interactional orientations that might be noticed here seems to be illusory. Investigative interviews are necessarily delimited by the legal procedures and institutional norms that standardize and stiffen the overall structural organization of the whole activity and each of its components. In practice, the regulations help investigators to navigate through the interview's phases, build coherence (Robinson 2013), and follow the procedures. At the same time, they may hamper the interactional character of the interview, which assumes a more local orientation and, in the Norwegian settings, less formal and rather relaxed communication. However, this is a trap that seems to paralyze those investigators who treat the information phase as a procedure of its own. When reduced to the recitation of the law (even simplified), it gives no space for comprehension checks and poses a great challenge to the assumptions of the KREATIV framework. 


\section{Discussion and Conclusions}

Our comparative analysis shows that the problems inherent in the delivery of scripted rights are equally apparent in "unscripted" communication, and L2 speakers' inability to understand their rights may pass undetected in both types of communication. Asked directly "Do you understand?", they may answer "yes" out of fear, compliance, or deference to authority and sign the waiver in a mistaken belief that they are giving up the rights to a prison lawyer and exercise in a prison yard (Pavlenko, Hepford and Jarvis 2019).

In 2015, a group of 21 linguists, psychologists, lawyers, and interpreters in Australia, England and Wales, and the US, known as the Communication of Rights Group (CoRG), articulated a set of workable recommendations for best practices in communicating scripted rights, titled Guidelines for Communication of Rights to Non-Native Speakers of English (CoRG, 2015). Our study allows us to expand these recommendations to contexts where delivery of rights is technically "unscripted" and to articulate recommendations for linguistic training suggested by the EU Directive (European Union 2012).

To begin with, we suggest that investigators need to be trained to slow down their presentation of rights - the information familiar to them may be very new to the interlocutors. Second, they need to learn how to rephrase the legal wording in more accessible language, i.e., by reducing density and complexity of the texts, splitting sentences with multiple clauses into shorter utterances, increasing the amount of repetition, and replacing legal jargon, low-frequency terms, and idiomatic expressions with high-frequency equivalents (additional suggestions can be found at http://plainlanguagenetwork .org). Having said this, we want to stress that we do not share the traditional belief that institutions can produce universally "comprehensible" texts. The fact that L2 speakers experience problems interpreting the very term "right" suggests that simplified wordings are a step towards securing understanding but not a magical solution.

Our third recommendation is to treat understanding as an interactional accomplishment and to train investigators on how to engage the suspects in the clarification process through contextualization and the use of reformulations, clarification questions, and comprehension checks. Most importantly, to comply with the aims of the ICCPR, we contend that understanding should not be determined by means of direct yes-or-no questions, such as "Do you understand?", or inferred from continuers, such as " $\mathrm{mhm}$ " or head nods. Following the Guidelines (CoRG, 2015), we recommend the adoption of an in-your-own-words requirement, whereby after presenting each right, investigators ask suspects to explain in their own words their understanding of that right and the consequences of waiving that right.

The adoption of such a requirement also serves another useful purpose - determining when the suspects need an interpreter. Since laypeople are rarely able to accurately assess their linguistic needs and the police lack the expertise to determine independently whether the suspect 
has sufficient understanding of the language in question, the adoption of an in-your-own-words requirement offers a working solution to this dilemma. When suspects have difficulties restating the rights in their own words (e.g., when they remain silent or repeat the statement verbatim), a professional interpreter with expertise in legal interpreting should be brought in, even if the suspect had earlier declined the offer of interpreting services. Then, the dialogic procedure needs to be repeated anew, because in and of itself the provision of interpreters and translations does not guarantee comprehension, especially among people unfamiliar with the very cultural assumptions underpinning the right to silence in police interviews.

\section{Transcription Conventions}

\section{Common}

:

/

yes

YES

${ }^{\circ}$ yes $^{\circ}$

[

$=$

(.)

(1.2)

((smiles))

US Interviews

$\downarrow$

$\uparrow$

?

Norwegian Interviews

$\uparrow \downarrow$

?

$\dot{\imath}$

,

$-$

-

$><$

.hh

(word)
(Extracts 1-4)

Lengthening of the preceding sound

Cut-off of the preceding word

Stress or emphasis

Noticeably louder speech, raised volume

Parenthetical comments made in a different tone

Onset of overlapping speech

Latched utterances, with no break or gaps between them

Brief untimed pause

Pauses with the duration in brackets in tenths of a second

The transcriber's descriptions

(Extracts 1 and 2)

Falling intonation contour

Rising intonation contour

Question intonation

(Extracts 3 and 4)

sharp changes in pitch (rise or fall)

strongly rising intonation

rising intonation

a slightly rising intonation

level intonation

falling intonation contour

faster talk

audible inhaling

uncertain fragment/alternative hearing

\section{Acknowledgments}

This work was partly supported by the Research Council of Norway through its Centers of Excellence funding scheme, project number 223265. 


\section{Notes}

1 Since the interviews in question were part of public suppression hearings, they are now in the public domain. Nevertheless, the second author also obtained permissions to use the data from the defendant (in the first case) and the District Attorney (in the second case).

2 KREATIV is an acronym for Kommunikasjon, Rettssikkerhet, Etikk og empati, Aktiv bevisstgjøring, Tillit giennom åpenhet, Informasjon, Vitenskapelig forankring (Communication, Rule of law, Ethics and empathy, Active awareness, Trust through openness, Information, Valid scientific foundation).

3 The Norwegian data come from the "Communicating Rights in Police Investigative Interviews" project at the Center for Multilingualism in Society across the Lifespan, University of Oslo. The recordings of interviews have been collected by permission of the Director of Public Prosecutions (Riksadvokaten), the Norwegian Center for Research Data, the Data Protection Officer at the University of Oslo, and Oslo Police District. The collection and management of the data are in accordance with the rules outlined by the Norwegian Center for Research Data and the guidelines of the Norwegian National Research Ethics Committees.

\section{References}

Berk-Seligson, S. 2002. “The Miranda Warnings and Linguistic Coercion: The Role of Footing in the Interrogation of a Limited-English-Speaking Murder Suspect.” In Language in the Legal Process, edited by J. Cotterill, 127-143. London: Palgrave Macmillan.

Berk-Seligson, S. 2009. Coerced Confessions: The Discourse of Bilingual Police Interrogations. Berlin: Mouton De Gruyter.

Berk-Seligson, S. 2016. "Totality of Circumstances and Translating the Miranda Warnings." In Discursive Constructions of Consent in the Legal Process, edited by S. Ehrlich, D. Eades, and J. Ainsworth, 241-263. Oxford, UK: Oxford University Press.

Bjerknes, O., and I. Fahsing. 2018. Etterforskning: Prinsipper, metoder og praksis. [Criminal Investigation: Principles, Methods and Practice]. Bergen: Fakbokforlaget.

Bjerknes, O., and E. Williksen. 2015. Politirapport: 4. Utgave [Police Report: 4th ed.]. Drammen: Forlaget Vett \& Viten.

Bloomfield, A., S. Wayland, E. Rhoades, A. Blodgett, J. Linck, and S. Ross. 2010. What Makes Listening Difficult? Factors Affecting Second Language Listening Comprehension. College Park, MD: University of Maryland.

Bowen, A. 2019. “'You Don't Have to Say Anything': Modality and Consequences in Conversations about the Right to Silence in the Northern Territory." Australian Journal of Linguistics 39, no. 3: 347-374.

CoRG. 2015. "Guidelines for Communicating Rights to Non-native Speakers of English in Australia, England and Wales, and the USA.” https://www.aaal.org/ guidelines-for-communication-rights (Accessed October 2, 2020).

Eades, D. 2010. Sociolinguistics and the Legal Process. Bristol, UK: Multilingual Matters.

Eades, D. 2018. "Communicating the Right to Silence to Aboriginal Suspects: Lessons from Western Australia v Gibson.” Journal of Judicial Administration 28: 4-21. 
Eggington, W., and T. Cox. 2013. "Using Elicited Oral Response Testing to Determine the Need for an Interpreter." Harvard Latino Law Review 16: 127-146.

Ehrlich, S., D. Eades, and J. Ainsworth. 2016. Discursive Constructions of Consent in the Legal Process. Oxford, UK: Oxford University Press.

Einesman, F. 2010. "Cultural Issues in Motions to Suppress Statements." In Cultural Issues in Criminal Defense, edited by L. Friedman Ramirez, 559-628. Huntington, NY: Juris Publishing.

Ellis, R. 2008. The Study of Second Language Acquisition. 2nd ed. Oxford, UK: Oxford University Press.

European Union. 2012. "Directive 2012/13/EU of the European Parliament and of the Council of 22 May 2012 on the Right to Information in Criminal Proceedings." Official Journal of the European Union L142, no. 55: 1-10. https:// eur-lex.europa.eu/LexUriServ/LexUriServ.do?uri=OJ:L:2012:142:0001:0010:en: PDF (Accessed May 1, 2020).

Fahsing, I., and K. Kepinska Jakobsen. 2016. "Investigative Interviewing of Suspects in Scandinavia." In International Developments and Practices in Investigative Interviewing and Interrogation. Volume 2: Suspects, edited by D. Walsh, G. Oxburgh, A. Redlich, and T. Myklebust, 180-192. London: Routledge.

Fahsing, I., and A. Rachlew. 2009. "Investigative Interviewing in the Nordic Region.” In International Developments in Investigative Interviewing, edited by T. Williamson, B. Milne, and S. Savage, 39-65. Cullompton: Willan Publishing.

Gudjonsson, G. 2018. The Psychology of False Confessions: Forty Years of Science and Practice. Hoboken, NJ: Wiley.

Heydon, G. 2005. The Language of Police Interviewing: A Critical Analysis. New York: Palgrave Macmillan.

Inbau, F., J. Reid, J. Buckley, and B. Jayne. 2013. Criminal Interrogation and Confession. 5th ed. Burlington, MA: Jones \& Bartlett Learning.

Innes, B., and R. Erlam. 2018. "Did She Understand Her Rights? Assessing the Comprehensibility of Police Cautions in New Zealand." The International Journal of Speech, Language and the Law 25, no. 1: 21-51.

Leo, R. 2008. Police Interrogation and American Justice. Cambridge, MA: Harvard University Press.

Pavlenko, A. 2008. “I'm Very not about the Law Part”: Non-native Speakers of English and the Miranda Warnings." TESOL Quarterly 42, no. 1: 1-30.

Pavlenko, A., E. Hepford, and S. Jarvis. 2019. "An Illusion of Understanding: How Native and Non-native Speakers of English Understand (and Misunderstand) Their Miranda Rights." The International Journal of Speech, Language and the Law 26, no. 2: 181-207.

Riksadvokaten. 2016. "Politiavhør" [Police interview]. Rundskriv fra Riksadvokaten 2/2016.

Robinson, J. 2013. "Overall Structural Organization." In The Handbook of Conversation Analysis, edited by J. Sidnell, and T. Stivers, 257-280. Malden, MA: Wiley-Blackwell.

Rock, F. 2007. Communicating Rights: The Language of Arrest and Detention. Basingstoke: Palgrave Macmillan.

Rock, F. 2016. "Talking the Ethical Turn: Drawing on Tick-Box Consent in Policing." In Discursive Constructions of Consent in the Legal Process, edited by S. Ehrlich, D. Eades, and J. Ainsworth, 93-117. Oxford, UK: Oxford University Press. 


\section{Pawet Urbanik and Aneta Pavlenko}

Rogers, R., and E. Drogin. 2019. Conducting Miranda Evaluations: Applications of Psychological Expertise and Science within the Forensic Context. Cham: Springer.

Rogers, R., C. Fiduccia, E. Drogin, J. Steadham, J. Clark, and R. Cramer. 2013. "General Knowledge and Misknowledge of Miranda Rights: Are Effective Miranda Advisements Still Necessary?" Psychology, Public Policy and Law 19, no. 4: 432-442.

Rogers, R., Harrison, K., Shuman, D., Sewell, K., and L. Hazelwood. 2007. “An Analysis of Miranda Warnings and Waivers: Comprehension and Coverage.” Law and Human Behavior 31: 177-192.

Rogers, R., L. Hazelwood, K. Sewell, K. Harrison, and D. Shuman. 2008. "The Language of Miranda Warnings in American Jurisdictions: A Replication and Vocabulary Analysis." Law and Human Behavior 32: 124-136.

Schegloff, E. 1982. "Discourse as an Interactional Achievement: Some Uses of 'Uh Huh' and Other Things that Come between Sentences." In Analyzing Discourse: Text and Talk, edited by D. Tannen, 71-93. Washington, DC: Georgetown University Press.

Scherr, K., and S. Madon. 2013. "“Go Ahead and Sign”: An Experimental Examination of Miranda Waivers and Comprehension." Law and Human Behavior 37, no. 3: 208-218.

Shawyer, A., B. Milne, and R. Bull. 2009. "Investigative Interviewing in the UK." In International Developments in Investigative Interviewing, edited by $\mathrm{T}$. Williamson, B. Milne, and S. Savage, 24-38. Cullompton: Willan Publishing.

Shuy, R. 1997. “Ten Unanswered Language Questions about Miranda.” Forensic Linguistics 4, no. 2: 175-196.

Svennevig, J. 2018. "Decomposing Turns to Enhance Understanding by L2 Speakers." Research on Language and Social Interaction 51, no. 4: 398-416.

Svennevig, J., J. Gerwing, B. U. Jensen, and M. Allison. 2019. "Pre-empting Understanding Problems in L1/L2 Conversations: Evidence of Effectiveness from Simulated Emergency Calls.” Applied Linguistics 40, no. 2: 205-227.

United Nations. 1966. "The International Covenant on Civil and Political Rights. Adopted by United Nations General Assembly." https://treaties.un.org/doc/ publication/unts/volume\%20999/volume-999-i-14668-english.pdf (Accessed October 2, 2020).

Vandergrift, L., and S. Baker. 2018. "Learner Variables Important for Success in L2 Listening Comprehension in French Immersion Classrooms." The Canadian Modern Language Review 74, no. 1: 79-100.

Villalobos, G., and D. Davis. 2016. "Interrogation and the Minority Suspect: Pathways to True and False Confession." In Advances in Psychology and Law, edited by M. Miller, and B. Bornstein, 1-42. Cham: Springer.

\section{Cases Cited}

Miranda v. Arizona, 384 U.S. 436 (1966).

Moran v. Burbine, 475 U.S. 412 (1986).

State v. Malinovskaya, "Superior Court of Delaware, New Castle County, Decision on Motion to Suppress." https://casetext.com/case/state-v-malinovskaya-1 (Accessed November 26, 2020). 